\title{
Subsoiling and Planting Method on the Initial Growth of 'Pera' Sweet Orange (Citrus sinensis (L.) Osbeck)
}

\author{
Thaís N. Meneses ${ }^{1}$, Mauricio A. Coelho Filho ${ }^{1,2}$, Hermes P. Santos Filho ${ }^{2}$, Luana L. A. Santos ${ }^{1}$, \\ Abelmon S. Gesteira ${ }^{2}$, Walter S. Soares Filho ${ }^{2}$ \& Orlando S. Passos ${ }^{2}$ \\ ${ }^{1}$ Federal University of Recôncavo of Bahia, Cruz das Almas, Bahia, Brazil \\ ${ }^{2}$ Embrapa Cassava and Fruits, Cruz das Almas, Bahia, Brazil \\ Correspondence: Mauricio A. Coelho Filho, Embrapa Cassava and Tropical Fruits, Embrapa s/n, CP. 07, Cruz \\ das Almas, Bahia, Brazil. Tel: 55-753-312-8022. E-mail: mauricio-antonio.coelho@embrapa.br
}

Received: January 3, 2019

Accepted: April 14, 2019

Online Published: June 30, 2019

doi:10.5539/jas.v11n9p1

URL: https://doi.org/10.5539/jas.v11n9p1

\begin{abstract}
The objective of this work was to evaluate the vegetative vigor and root architecture of 'Pera CNPMF D-6' sweet orange grafted on Rangpur lime at early stage of development, submitted to different planting methods (planting of nursery trees produced in a protected environment-PNT and planting of seeds at the definitive place-PS) and soil preparation with and without subsoiling. The experiment was carried out at the Lagoa do Coco Farm, Rio Real, Bahia, Brazil. Biometric evaluations were performed to estimate the variables: canopy volume (CV), vegetative vigor index (VVI) and canopy cover rates in the planting row (CCR-R) and interrow (CCR-I). Root samples were also collected up to a depth of $1.45 \mathrm{~m}$ at five points in the planting row. The roots were digitized and processed to obtain total root length (TRL), root length density (RLD), average root diameter (RD) and root length for the diameter classes. Plants produced in protected environment exhibit greater shoot vegetative and root development compared to those produced by sowing at the definitive place, at least for the young orchard and under rainfed conditions. Subsoiling did not affect root system distribution and PNT favored the increase in TRL along the soil profile compared to PS, for all diameter classes evaluated, contributing to the increase in vegetative vigor observed in the plants. Regardless of the management practices adopted, roots were concentrated in the first $0.35 \mathrm{~m}$ of the vertical soil profile, due to physical impediment caused by the presence of cohesive horizons.
\end{abstract}

Keywords: Citrus spp., cohesive soils, nursery tree, root system, plant vigor

\section{Introduction}

Citriculture has great economic importance worldwide and in Brazil, generates millions of direct and indirect jobs and contributes to strengthening the economy of the producing countries (Neves et al., 2010). In 2017, Brazil produced 17,459,908 tons of orange [Citrus sinensis (L.) Osbeck]. The Northeast region participated with $7.25 \%$ in this production, $1,266,525$ tons of orange, the Bahia state was responsible for the production of 665,986 tons of this total (IBGE, 2017).

Among the cultivars of sweet orange used in the juice industry and for fresh consumption, 'Pera' sweet orange (C. sinensis) is the most produced and consumed in Brazil, occupying almost all cultivated areas in the states of Bahia and Sergipe (Passos, Cunha Sobrinho, \& Soares Filho, 2013).

In Northeast Brazil, citrus production is established on the Coastal Tablelands, which are characterized by irregular rainfall distribution and the physical, chemical and physical-hydraulic limitations of its main soils, and because of that do not provide adequate environmental conditions for the growth and yield of citrus orchards (Martins, Teodoro, \& Carvalho, 2014; Rezende, Shibata, \& Souza, 2015). Among the aspects of the physical medium acting on citrus root system development in soils of Coastal Tablelands, cohesive horizons and its effects on the increase of soil mechanical resistance, poor oxygenation and low water availability to plants during the dry season are among the most important ones (Cintra, 2006, 2011).

Previous studies have demonstrated that a better understanding on root system distribution contributes to increasing citrus yield and longevity, mainly in soils which have cohesive subsurface horizons (L. D. Souza, Ribeiro, L. S. Souza, Ledo, \& Cunha Sobrinho, 2006; Santana, L. S. Souza, L. D. Souza, \& Fontes, 2006; Souza, 
Paiva, Rodrigues, \& Ribeiro, 2008; Zaccheo, Neves, Srenzel, \& Okumura, 2012) and in regions with long periods of drought, even in areas where conventional subsoiling has been carried out for orchard planting (Medeiros, Figueiredo, Mafra, Rosa, \& Yoon, 2013).

A quality citrus seedling is one of the most important factors in the planting of a commercial orchard, due to the perennial character of the citrus crop (Davoglio Junior, Bordin, \& Neves, 2006). Traditionally, the process of production of citrus nursery trees (PNT) and subsequent planting at the definitive place lead to circling roots and successive cuts in the transplanting steps (seed tray/nursery/orchard). Consequently, the taproot system loses dominance and is replaced by a fasciculated root system, which tends to concentrate in the superficial horizons, contributing to orchard vulnerability to environmental adversities (Rezende, 2011). Such practice, according to Baldassari, Goes, and Tannuri (2003), entails a severe morphological deformation of the root system in citrus seedlings, reducing their growth potential after field transplanting. The low quality of nursery plants could be related to the serious problems associated with the proper selection of plants in the nursery, for example, the need for discarding the zygotic seedlings to guarantee the genetic potential of rootstock variety and discarding seedlings with root malformation. On the other hand, the quality of the PNT is crucial for perennial trees and explains the greater variability of vigor and yield of plants in the field.

Currently, studies conducted in partnership with Bahia's citriculture have focused on sowing the rootstock at the definitive place (PS), as a way to minimize the restrictions imposed by cohesive horizons. According to Rezende (2013) and Rezende, Shibata and Souza (2015), the original architecture of the intact root system promotes greater root deepening and higher tolerance to drought in citrus, allowing effective exploration of the soil. Improvements in soil physical quality have been observed in the association of no tillage in citrus with soil management (Fidalski, Barbosa, Auler, Pavan, \& Beraldo, 2009; González Peñaloza et al., 2012).

The present study aimed at evaluating the vegetative vigor and root system architecture of young 'Pera' orange plants subjected to different methods of planting and soil preparation, in order to gather information that may help in future management practices.

\section{Method}

\subsection{Experimental Characterization: Soil, Climate and Establishment of Treatments}

The experiment was conducted in a commercial orchard of 'Pera CNPMF-D6' orange grafted on 'Santa Cruz' Rangpur lime (C. limonia Osbeck), planted in 2015, at the Lagoa do Coco Farm, situated in the municipality of Rio Real-Bahia, Brazil (latitude $11^{\circ} 34^{\prime} 26^{\prime \prime} \mathrm{S}$, longitude $37^{\circ} 52^{\prime} 39^{\prime \prime} \mathrm{W}$ and $170 \mathrm{~m}$ of altitude), in an area of 16,128 $\mathrm{m}^{2}(128 \times 126 \mathrm{~m})$, spaced by $6.0 \mathrm{~m} \times 2.0 \mathrm{~m}$, under rainfed conditions.

According to Köppen's classification, the climate of the area is As, hot and humid, with mean annual temperature of $24.1^{\circ} \mathrm{C}$ and mean annual rainfall of $1100 \mathrm{~mm}$, rainy period from May to July and a drier period between October and December. The soil is Argisolic Dystrocohesive Yellow Latosol (Ferralsols) of Coastal Tablelands, and its physical-hydraulic and chemical attributes are shown in Tables 1 and 2, respectively.

Table 1. Distribution of sand, silt and clay, textural class, bulk density (BD), hydraulic conductivity (K0) and resistance to penetration (RP) along the profile of an Argisolic Dystrocohesive Yellow Latosol (Ferralsols). Lagoa do Coco Farm, BA, Brazil

\begin{tabular}{llllllll}
\hline Horizon/Depth & Sand & Silt & Clay & Textural & $\mathrm{BD}$ & $\mathrm{K} 0$ & $\mathrm{RP}$ \\
\hline $\mathrm{m}$ & $---------\mathrm{g} \mathrm{kg}^{-1}$ & -------- & Class & $\mathrm{g} \mathrm{cm}^{-3}$ & $\mathrm{~cm} \mathrm{~h}^{-1}$ & $\mathrm{MPa}$ \\
$\mathrm{A}(0.00-0.18)$ & 746 & 58 & 196 & Sandy loam & 1.48 & 0.84 & 1.07 \\
$\mathrm{AB}(0.18-0.39)$ & 726 & 72 & 202 & Sandy clay loam & 1.61 & 0.47 & 2.74 \\
BA $(0.39-0.68)$ & 661 & 63 & 276 & Sandy clay loam & 1.75 & 0.09 & 5.25 \\
BW1 $(0.68-1.07)$ & 644 & 36 & 320 & Sandy clay loam & 1.41 & & \\
BW2 (1.07-1.65+) & 624 & 60 & 316 & Sandy clay loam & 1.50 & & \\
\hline
\end{tabular}

Source: Calfa, 2010. 
Table 2. Chemical attributes of Argisolic Dystrocohesive Yellow Latosol (Ferralsols) of the experimental area in January 2019. Lagoa do Coco Farm, BA, Brazil

\begin{tabular}{|c|c|c|c|c|c|c|c|c|c|c|c|c|}
\hline Depth & $\mathrm{pH}$ & $\mathrm{OM}$ & $\mathrm{P}$ & $\mathrm{K}$ & $\mathrm{Ca}$ & $\mathrm{Mg}$ & $\mathrm{Al}$ & $\mathrm{Na}$ & $\mathrm{H}+\mathrm{Al}$ & SB & CEC & $\mathrm{V}$ \\
\hline $\mathrm{m}$ & $\mathrm{H}_{2} \mathrm{O}$ & $\mathrm{g} \mathrm{kg}^{-1}$ & $\mathrm{mg} \mathrm{dm}^{-3}$ & ---- & ----- & ---- & $-\mathrm{cr}$ & $l_{c} \mathrm{dm}^{-3}$ & --------- & ------ & ------- & $\%$ \\
\hline $0.00-0.20$ & 6.3 & 11.0 & 5 & 0.08 & 2.25 & 0.43 & 0 & 0.05 & 1.21 & 2.81 & 4.02 & 70 \\
\hline $0.20-0.40$ & 6.1 & 8.0 & 2 & 0.05 & 1.42 & 0.39 & 0 & 0.05 & 1.21 & 1.91 & 3.12 & 61 \\
\hline
\end{tabular}

Note. * OM, organic matter; P, phosphorus; K, potassium; Ca, calcium; Mg, magnesium; Na, sodium; Al, aluminum; $\mathrm{H}+\mathrm{Al}$, total acidity; $\mathrm{SB}$, sum of bases; $\mathrm{CEC}$, cation exchange capacity and $\mathrm{V}$, base saturation.

The experiment was conducted in a randomized strip-block design, to facilitate the physical operations of soil mechanization. Treatments consisted of the combination of two planting methods [planting of nursery trees produced in protected environment (PNT) and planting of seeds at the definitive place (PS)] and two forms of soil preparation [with subsoiling (WS) and without subsoiling (WOS) at $0.75 \mathrm{~m} \mathrm{depth}$ ], with eight replications. The experimental plot consisted of five planting rows, with four plants each, and the six central plants were used for evaluations.

Propagative materials (seeds, buds and protected seedlings) were obtained at the National Research Center on Cassava and Fruits-CNPMF. In both treatments, the rootstock was sown in the same period and grafting by budding was performed one year after sowing. The sowing of the rootstocks at the definitive place was carried out in May 2014, early rainy period, aiming at better use of rainwater. Seeds (15 to 20) were placed in the planting furrow and, from the fifth month, thinning was performed to eliminate plants derived from zygotic embryos and less vigorous plants. In June 2015, grafting was carried out in the field at the same time as seedlings were planted in a screened nursery.

\subsection{Biometric Evaluations of Plant Shoots}

At the $18^{\text {th }}$ month after orchard establishment, the following variables were measured: plant height (m), canopy diameter in the planting row and interrow $(\mathrm{m})$ and rootstock stem diameter, at $5 \mathrm{~cm}$ below and above the grafting point $(\mathrm{mm})$, in a total of 16 plants, selecting one plant from each plot.

These data were used to calculate, according to Portella et al. (2016), the canopy cover rate in the row (CCR-R), canopy cover rate in the interrow (CCR-I), vegetative vigor index (VVI) and mean canopy volume (CV), according to the equations:

$$
\mathrm{CCR}-\mathrm{R}=\left(\mathrm{D}_{\text {row }} / \mathrm{S}\right) \times 100
$$

expressed in percentage, where, $\mathrm{D}_{\text {row }}$ : canopy diameter along the planting row $(\mathrm{m})$; $\mathrm{S}$ : spacing used in the planting row $(\mathrm{m})$,

$$
\text { CCR-I }=\left(D_{\text {interrow }} / \mathrm{S}\right) \times 100
$$

expressed in percentage, where, $\mathrm{D}_{\text {interrow}}$ : canopy diameter toward the interrow $(\mathrm{m})$; $\mathrm{S}$ : spacing used in the interrow $(\mathrm{m})$,

$$
\mathrm{VVI}=[\mathrm{H}+\mathrm{CD}+(\mathrm{RSD} \times 1000)] / 100
$$

dimensionless, where, H: plant height (m); CD: mean canopy diameter (m); RSD: rootstock stem diameter (mm),

$$
\mathrm{CV}=(\pi / 6) \times \mathrm{H} \times \mathrm{D}_{\text {row }} \times \mathrm{D}_{\text {interrow }}
$$

expressed in $\mathrm{m}^{3}$, where, $\mathrm{H}$ : plant height $(\mathrm{m})$; $\mathrm{D}_{\text {row }}$ : canopy diameter along the planting row $(\mathrm{m})$; $\mathrm{D}_{\text {interrow}}$ : canopy diameter toward the interrow $(\mathrm{m})$.

\subsection{Evaluations of Root System}

For root architecture analysis, 12 plants were selected encompassing both planting methods (PS and PNT) and both forms of soil preparation (WS and WOS), in a total of three replicates.

At 15 months of orchard growth, soil samples were collected with a Dutch auger $\left(877 \mathrm{~cm}^{3}\right)$ at five points perpendicular to the planting row, at $0.50 \mathrm{~m}$ distance from the stem and horizontally spaced by $0.20 \mathrm{~m}$, at five depths $(0.0-0.15,0.15-0.35,0.35-0.60,0.60-0.95$ and $0.95-1.45 \mathrm{~m})$. These sampling positions were defined based on the horizons classified according to Calfa (2010).

In the laboratory, mass and moisture content of the samples were determined and roots were separated from the soil by immersion in water and sieving (1-mm mesh), and stored in $30 \%$ alcohol, at $4{ }^{\circ} \mathrm{C}$. After that, they were 
digitized using a scanner (EPSON Expression 11000 XL) with 400 dpi resolution image and processed by the program WinRhizo ${ }^{\circledR}$ Pro 2013 (Regent Instruments Canada Inc., Quebec, Canada) to obtain the variables: average root diameter $(\mathrm{RD})$, root length for the diameter classes (0.0-1.0, 1.0-2.0 and $>2 \mathrm{~mm})$, and total root length (TRL). Root length density (RLD) was calculated as the ratio between the TRL of each sample and soil volume, obtained based on the mass/volume ratio and on the bulk density in the soil profile according to Calfa (2010).

\subsection{Statistical Analysis}

The data were subjected to analysis of variance by $F$ test and Tukey test $(p<0.05)$ to compare the effects of factors and analyze their interactions for the studied variables, when significant.

\section{Results and Discussion}

There was no significant interaction between the methods of planting and soil preparation for the shoot growth variables. The planting of nursery trees (PNT) favored the growth in rootstock diameter (RSD) and increase in canopy volume $(\mathrm{CV})$, vegetative vigor index (VVI) and canopy cover rates in the planting row (CCR-R) and interrow (CCR-I). The forms of soil preparation affected the physiological indices CV, VVI and CCR-R, contrary to the expectations, the treatment without subsoiling was superior to that with subsoiling. No significant differences among treatments were found in plant height $(\mathrm{H})$ (Table 3 ).

Table 3. Statistical summary and means of height $(\mathrm{H})$, rootstock diameter (RSD), canopy volume (CV) vegetative vigor index (VVI), canopy cover rate in the planting row (CCR-R) and canopy cover rate in the interrow (CCR-I) of 'Pera' orange [Citrus sinensis (L.) Osbeck]/Rangpur lime (C. limonia Osbeck) combinations, at 18 months after orchard establishment, under different forms of soil preparation (with subsoiling-WS and without subsoiling-WOS) and planting methods (nursery trees produced in protected environment-PNT and planting of seeds at the definitive place-PS), Lagoa do Coco Farm, Rio Real-Bahia, Brazil, December 2016

\begin{tabular}{lllllll}
\hline Factor & $\mathrm{H}(\mathrm{m})$ & RSD $(\mathrm{mm})$ & $\mathrm{CV}\left(\mathrm{m}^{3}\right)$ & $\mathrm{VVI}$ & CCR-R (\%) & CCR-I (\%) \\
\hline Planting (A) & $0.294 \mathrm{~ns}$ & $0.001^{* *}$ & $0.013^{*}$ & $0.002^{*}$ & $0.012^{*}$ & $0.015^{*}$ \\
Subsoiling (B) & $0.153 \mathrm{~ns}$ & $0.699 \mathrm{~ns}$ & $0.034^{*}$ & $0.035^{*}$ & $0.028^{*}$ & $0.070 \mathrm{~ns}$ \\
$\mathrm{~A} \times \mathrm{B}$ & $0.423 \mathrm{~ns}$ & $0.346 \mathrm{~ns}$ & $0.225 \mathrm{~ns}$ & $0.557 \mathrm{~ns}$ & $0.259 \mathrm{~ns}$ & $0.660 \mathrm{~ns}$ \\
\hline Planting $(A)$ & & & & & \\
Protected seedling & $1.21 \mathrm{a}$ & $46.01 \mathrm{a}$ & $0.67 \mathrm{a}$ & $2.69 \mathrm{a}$ & $48.31 \mathrm{a}$ & $17.94 \mathrm{a}$ \\
Seed & $1.16 \mathrm{a}$ & $32.36 \mathrm{~b}$ & $0.44 \mathrm{~b}$ & $2.33 \mathrm{~b}$ & $39.56 \mathrm{~b}$ & $14.77 \mathrm{~b}$ \\
\hline Subsoiling $(B)$ & & & & & \\
With subsoiling & $1.15 \mathrm{a}$ & $38.59 \mathrm{a}$ & $0.46 \mathrm{~b}$ & $2.40 \mathrm{~b}$ & $40.25 \mathrm{~b}$ & $15.25 \mathrm{a}$ \\
Without subsoiling & $1.22 \mathrm{a}$ & $39.79 \mathrm{a}$ & $0.67 \mathrm{a}$ & $2.62 \mathrm{a}$ & $47.63 \mathrm{a}$ & $17.46 \mathrm{a}$ \\
CV (\%) & 7.87 & 15.47 & 28.96 & 7.59 & 13.44 & 13.59 \\
\hline
\end{tabular}

Note: $* *$ and $*$ significant at $1 \%$ and $5 \%$ probability levels, respectively, by Tukey test, ns not significant. Means followed by the same letters in the column do not differ by Tukey test at 0.05 significance level.

The planting methods affected total root length (TRL), root length density (RLD) and root length for the classes of diameter, and the planting of protected seedlings (PNT) was statistically superior to the planting of seeds at the definitive place (PS). There was no significant effect of subsoiling on the root system and no interaction between subsoiling and planting methods, except for root length density (RLD) (Table 4). There was increase in RLD due to the planting of protected seedlings (PNT) under the condition without subsoiling (WOS) (Figure 1A). The management practices adopted did not affect the average root diameter (RD) (Table 4), with higher root concentration in the first $0.60 \mathrm{~m}$ (Figure 1B). 
Table 4. Statistical summary and means of total root length (TRL), root length density (RLD), root diameter (RD) and root length for the diameter classes (0.0-1.0, 1.0-2.0 and $>2 \mathrm{~mm}$ ) of 'Pera' orange [Citrus sinensis (L.) Osbeck]/Rangpur lime (C. limonia Osbeck) combination, at 15 months after orchard establishment, under different forms of soil preparation (with subsoiling-WS and without subsoiling-WOS) and planting methods (nursery trees produced in protected environment-PNT and planting of seeds at the definitive place-PS), Lagoa do Coco Farm, Rio Real - Bahia, Brazil, September 2016

\begin{tabular}{|c|c|c|c|c|c|c|}
\hline \multirow{2}{*}{ Factor } & \multirow{2}{*}{ TRL $(\mathrm{cm})$} & \multirow{2}{*}{$\operatorname{RLD}\left(\mathrm{cm} \mathrm{cm}^{-3}\right)$} & \multirow{2}{*}{$\mathrm{RD}(\mathrm{mm})$} & \multicolumn{3}{|c|}{ Root diameter class $(\mathrm{mm})$} \\
\hline & & & & $0-1$ & $1-2$ & $>2$ \\
\hline Planting (A) & $0.0002 * *$ & $0.0046^{* *}$ & $0.3724 \mathrm{~ns}$ & $0.0003 * *$ & $0.0039 * *$ & $0.0366^{*}$ \\
\hline Subsoiling (B) & $0.2496 \mathrm{~ns}$ & $0.0175^{* *}$ & $0.1748 \mathrm{~ns}$ & $0.2531 \mathrm{~ns}$ & $0.5710 \mathrm{~ns}$ & $0.9366 \mathrm{~ns}$ \\
\hline Depth (C) & $0.0001 * *$ & $0.0455^{*}$ & $0.0010 * *$ & $0.0001 * *$ & $0.0847 \mathrm{~ns}$ & $0.0265 *$ \\
\hline $\mathrm{A} \times \mathrm{B}$ & $0.0738 \mathrm{~ns}$ & $0.0145^{*}$ & $0.2620 \mathrm{~ns}$ & $0.0539 \mathrm{~ns}$ & $0.9975 \mathrm{~ns}$ & $0.9367 \mathrm{~ns}$ \\
\hline $\mathrm{A} \times \mathrm{C}$ & $0.0069 * *$ & $0.1017 \mathrm{~ns}$ & $0.4564 \mathrm{~ns}$ & $0.0067 * *$ & $0.5236 \mathrm{~ns}$ & $0.0265^{*}$ \\
\hline $\mathrm{B} \times \mathrm{C}$ & $0.3077 \mathrm{~ns}$ & $0.1405 \mathrm{~ns}$ & $0.3712 \mathrm{~ns}$ & $0.2895 \mathrm{~ns}$ & $0.1920 \mathrm{~ns}$ & $0.6781 \mathrm{~ns}$ \\
\hline $\mathrm{A} \times \mathrm{B} \times \mathrm{C}$ & $0.6096 \mathrm{~ns}$ & $0.2640 \mathrm{~ns}$ & $0.0508 \mathrm{~ns}$ & $0.6711 \mathrm{~ns}$ & $0.0517 \mathrm{~ns}$ & $1.0000 \mathrm{~ns}$ \\
\hline \multicolumn{7}{|l|}{ Planting $(A)$} \\
\hline Protected seedling & $37.18 \mathrm{a}$ & $1.22 \mathrm{a}$ & $0.42 \mathrm{a}$ & $33.99 \mathrm{a}$ & $2.56 \mathrm{a}$ & $0.62 \mathrm{a}$ \\
\hline Seed & $11.38 \mathrm{~b}$ & $0.19 \mathrm{~b}$ & $0.37 \mathrm{a}$ & $10.98 \mathrm{~b}$ & $0.41 \mathrm{~b}$ & $0.00 \mathrm{~b}$ \\
\hline \multicolumn{7}{|l|}{ Subsoiling $(B)$} \\
\hline With subsoiling & $19.70 \mathrm{a}$ & $0.20 \mathrm{~b}$ & $0.37 \mathrm{a}$ & $18.28 \mathrm{a}$ & $1.14 \mathrm{a}$ & $0.27 \mathrm{a}$ \\
\hline Without subsoiling & $28.86 \mathrm{a}$ & $1.22 \mathrm{a}$ & $0.42 \mathrm{a}$ & $26.68 \mathrm{a}$ & $1.83 \mathrm{a}$ & $0.35 \mathrm{a}$ \\
\hline CV $(\%)$ & 98.65 & 186.98 & 56.89 & 98.76 & 183.04 & 357.87 \\
\hline
\end{tabular}

Note: ** and * significant at $1 \%$ and $5 \%$ probability levels, respectively, by Tukey test, ns not significant. Means followed by the same letters in the column do not differ by Tukey test at 0.05 significance level.

$\mathbf{A}$

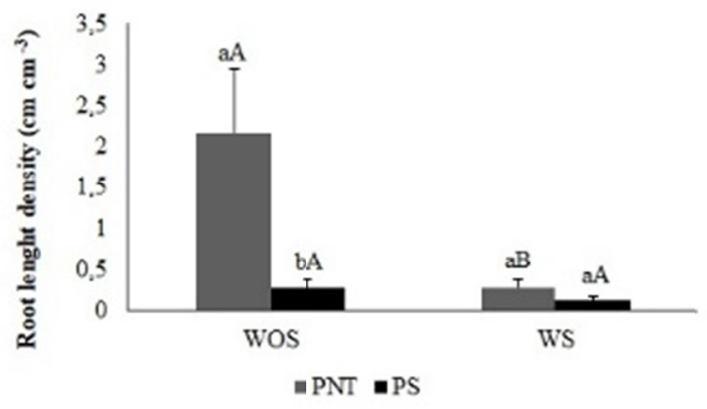

B

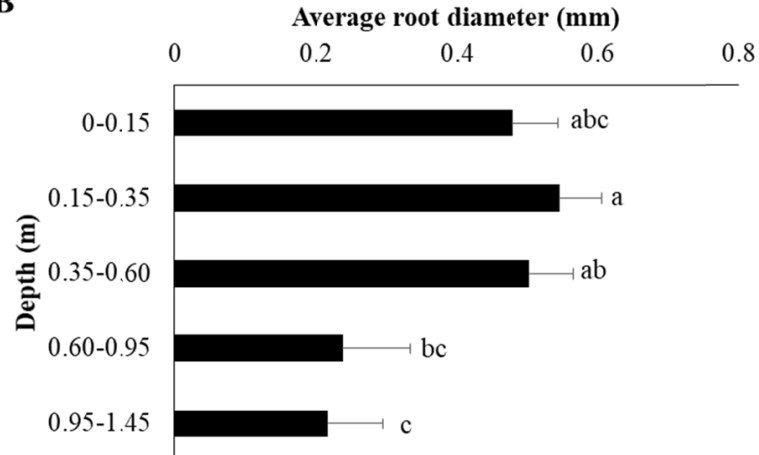

Figure 1. Mean values and standard error bars of root length density (A) of 'Pera' orange [Citrus sinensis (L.) Osbeck]/Rangpur lime (C. limonia Osbeck) combination, at 15 months after orchard establishment, under different forms of soil preparation (with subsoiling-WS and without subsoiling-WOS) and planting methods (nursery trees produced in protected environment-PNT and planting of seeds at the definitive place-PS) and average root diameter (A) along the soil profile, Lagoa do Coco Farm,

Rio Real-Bahia, Brazil, September 2016

Note. Means followed by the same lowercase letters do not differ by Tukey test $(\mathrm{p}<0.05)$. (Comparison between types of planting) and means followed by the same uppercase letters do not differ by Tukey test $(\mathrm{p}<0.05)$. (Comparison between soil managements).

There was interaction between planting systems and depths (Table 4), with differences in root length between the two types of planting up to $0-35 \mathrm{~cm}$ depth. Planting of protected seedlings (PNT) led to higher root length compared to the planting of seeds at the definitive place (PS) (Figures 2A and 2B). There were no roots in the diameter class $>2 \mathrm{~mm}$ for the planting of seeds at the definitive place (Figure 2C). Oliveira et al. (2018) observed in protected environment higher values of root diameter in the planting of 'Sunki Maravilha' mandarin seedlings when there was no limitation to root penetration, suggesting greater capacity of these plants to explore 
soils with good physical structure and porosity or that root deepening is enabled through cracks beyond the cohesive layer, which is contrary to the assumptions of gains with the sowing at the definitive place under field conditions.
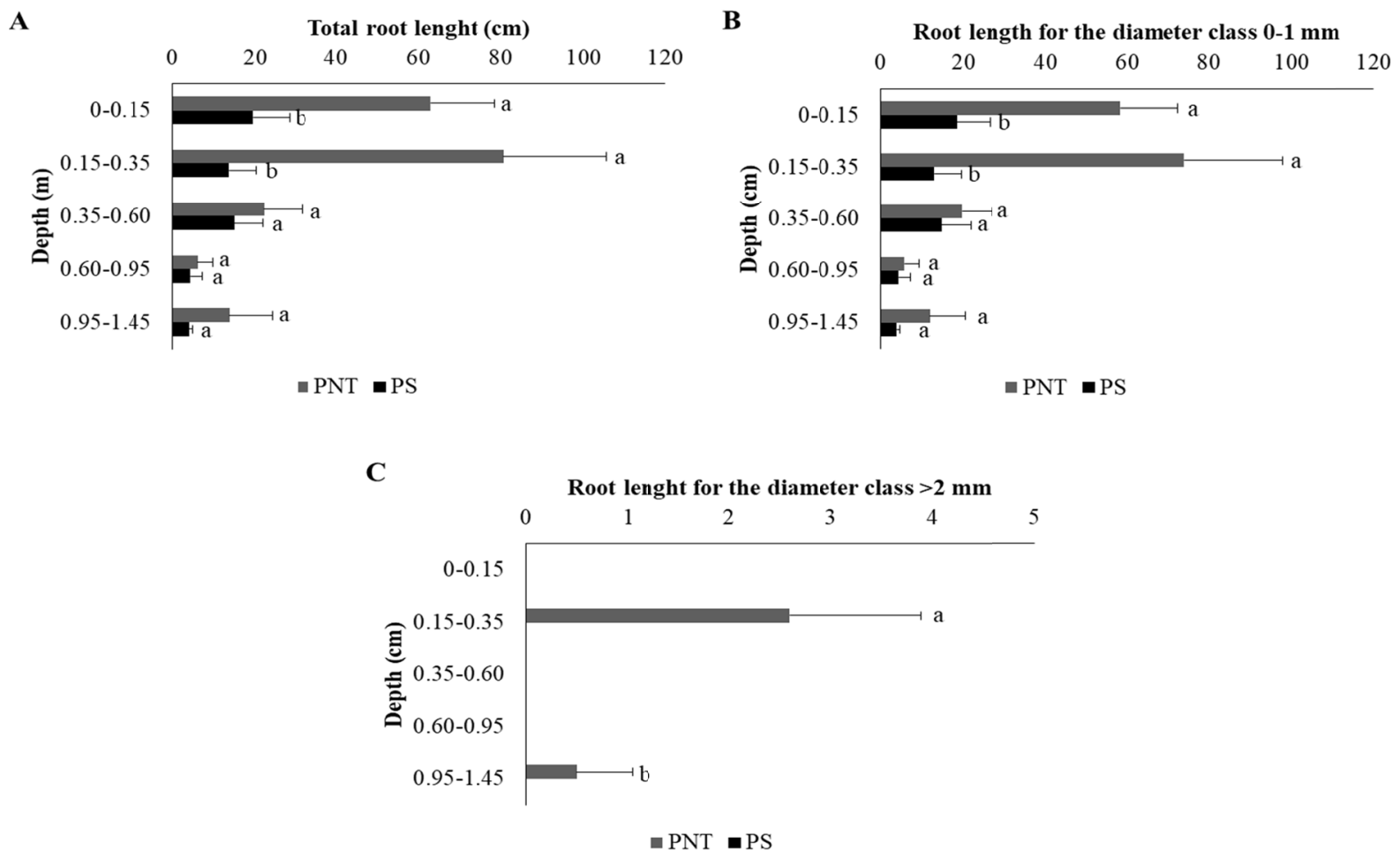

Figure 2. Means and standard errors of total root length (A) and root length for the diameter classes 0-1 mm (B) and $>2 \mathrm{~mm}(\mathrm{C})$ of 'Pera' orange [Citrus sinensis (L.) Osbeck]/Rangpur lime (C. limonia Osbeck) combination, under different planting methods (nursery trees produced in protected environment-PNT and planting of seeds at the definitive place-PS) along the soil profile. Lagoa do Coco Farm, Rio Real-Bahia, Brazil, September 2016

Note. Means followed by the same letters do not differ by Tukey test $(\mathrm{p}<0.05)$.

In general, roots were concentrated in the surface horizons from 0.0 to $0.35 \mathrm{~m}$ (Figure $2 \mathrm{~A}$ ), which is probably explained by the cohesion and compaction in the $\mathrm{AB}(0.18-0.39 \mathrm{~m})$ and $\mathrm{BA}(0.39-0.68 \mathrm{~m})$ horizons, based on the soil classification carried out by Calfa (2010). According to L. D. Souza, Cunha Sobrinho, Ribeiro, L. S. Souza, and Ledo (2004), these horizons have a visible reduction of macropores and abrupt reduction of root concentration, compared to overlying and underlying horizons. Corroborating the present study, due to the restrictions to root deepening, imposed by the cohesive layer, L. D. Souza, L. S. Souza, and Ledo (2007) found that, regardless of the irrigation system (micro-sprinkler) and rainfed condition, the highest root densities of 'Pera' orange in the planting row and interrow are found at depths from 0 to $0.20 \mathrm{~m}$. Souza, Paiva, Rodrigues, and Ribeiro (2008) also found that roots of 'Hamlin' orange (C. sinensis), grafted on Rangpur lime, were highly sensitive to the presence of cohesion in soils Ferralsols of the Coastal Tablelands (Argisolic Yellow Latosol and Yellow Latosol), like the soil classified in our experiment, Argisolic Dystrocohesive Yellow Latosol (Ferralsols). Santana, L. S. Souza, L. D. Souza, and Fontes (2006) found $87 \%$ of roots $\left(\mathrm{cm}^{-\mathrm{cm}^{-3}}\right.$ of soil) at depths from 0.0 to $0.38 \mathrm{~m}$ in two soils of the Coastal Tablelands of Bahia (Yellow Latosol and Gray Argisol).

Root system deepening is important to increase citrus yield and longevity, mainly in soils with cohesive subsurface horizons (Souza, Paiva, Rodrigues, \& Ribeiro, 2008) since root growth is mainly conditioned by the physical attributes of the soil where plants are cultivated (Jin et al., 2017). Soil structure is important especially in the case of perennial plants, which in the long term could avoid stressful environments and tend to find favorable soil conditions to proliferate. Therefore, concerning the present conditions studied, soil structure up to $0.35 \mathrm{~m}$ depth is more important for shoot and root vigor of 'Pera' sweet orange trees, because it concentrates larger root volume, which allows the uptake of water and nutrients necessary for their development. 
Concentration of thinner roots in the upper soil layers (Figure 2B) may be associated with the greater use of water in surface soil, an adaptive process of the plant to the irregular climatic events in the region and soil structure. This behavior may be a possible indication that plants under these conditions will acclimate better to climatic variability events related to water deficit, as observed by Coelho, Oliveira, Araújo, and Vasconcelos (2002) in 'Pera' orange orchard, where water distribution in the soil was determinant in the root distribution pattern. Higher concentration of thin roots $(0.5$ to $2 \mathrm{~mm})$ was observed in soil profiles under micro-sprinkler irrigation, compared to the non-irrigated condition.

Total root length and root length for the diameter classes tended to decrease in subsurface, and PNT was superior to PS along the profile (Figure 2). The results corroborate the fact that the presence of physical impediments to root growth close to soil surface (Table 1) increases root diameter, because it is an adaptive response to this abiotic stress (Gregory et al., 2009), as observed by Oliveira et al. (2018) for citrus. L. D. Souza, Ribeiro, L. S. Souza, Ledo, and Cunha Sobrinho (2006) also observed, in 'Valencia' orange grafted on 'Volkamer' lemon ( $C$. volkameriana Ten. \& Pasq.), reduction in root density from the smallest diameter to the largest diameter in the adopted classes of $\mathrm{d} 1<0.5,0.5<\mathrm{d} 2<1.0,1.0<\mathrm{d} 3<2.0, \mathrm{~d} 4>2.00 \mathrm{~mm}$, with percentage distribution of $44 \%$ for $\mathrm{d} 1,30 \%$ for $\mathrm{d} 2,17 \%$ for $\mathrm{d} 3$ and $9 \%$ for $\mathrm{d} 4$, which is greatly important according to the authors, because roots with smaller diameter are more active in the soil and, for Santos, Coelho, and Azevedo (2005), they favor water uptake and absorption of nutrients from the soil.

According to the results of the present study, the conventional planting of nursery trees (PNT) contributed to the increase in TRL along the soil profile (Figure 2A). Carvalho (2001) discussed that root pruning procedures performed in the conventional process of seedling production (PNT) force the growth of secondary roots, promoting higher root development. Oliveira et al. (2018), in a simulation of cohesive layer in protected environment, showed that the planting of seedlings, simulating the PNT, led to greater root development with physical impedance $<1.52 \mathrm{MPa}$, explained by the fact that this planting system already had structures of secondary roots favoring the increase of absorption roots. Additionally, 'Rangpur Cravo Santa Cruz' lime has a very vigorous root system, easily breaking the physical impedance, increasing root length density and root capacity to absorb water and nutrients, because of length increase of thin roots compared to plants originated from direct sowing (PS). The results of the present study demonstrate greater capacity to produce roots in PNT $\left(1.21 \mathrm{~cm} \mathrm{~cm}^{-3}\right)$, since it led to higher root density compared to PS $\left(0.19 \mathrm{~cm} \mathrm{~cm}^{-3}\right)$ in the field.

When the data were analyzed along with those of plant shoots, it was observed that the higher activity of the root system of plants grown from PNT, compared to PS, led to higher vegetative vigor in PNT, since it favored the increase in the canopy volume $(\mathrm{CV})$ and vegetative vigor index (VVI) of young 'Pera' orange plants, in comparison to PS (Figures 1 and 2, Tables 3 and 4). In protected environment, Oliveira et al. (2018) also verified that conventional planting (PNT) was associated with greater root and shoot vigor, indicating that, in soils with good physical structure and porosity or allowing root deepening beyond the cohesive layer, this planting system is completely adequate, despite the possible benefit of not cutting the pivoting root in direct sowing (PS). Davoglio Junior, Bordin, and Neves (2006) demonstrated the existence of correlation between the shoots and root system of 4-year-old citrus trees, due to the higher seedling vigor at planting and to the horizontal exploration of the soil by the roots. Therefore, regardless of soil management (WOS and WS), seedling quality in orchard planting (PNT) was important to maintain adequate growth of plants. Additionally, all phytosanitary, nutritional and edaphoclimatic managements were adequate in the nursery, whereas field plants would be subjected to adverse environmental conditions, affecting their development.

According to Baldassari, Goes, and Tannuri (2003), the ideal situation would be a straight and undivided taproot of citrus plants, at least up to the length of the plastic bags where seedlings are grown after transplanting the rootstock, because citrus seedlings with root malformation have limited growth of the root system to greater soil depths, when planted in the field, even if soil chemical and physical conditions are favorable. Thus, the selection in the nursery may have contributed to the greater performance of the citrus seedling in the field, highlighting the importance of seedling quality in orchard establishment.

Moreover, the genetic potential in conventionally produced seedlings of 'Pera CNPMF-D6' orange grafted on 'Santa Cruz' Rangpur lime (C. limonia Osbeck), in protected nursery, as found by Rodrigues et al. (2016) with superior leaf area, root system volume and taproot diameter, was greater than that of other combinations of this scion with the rootstocks HTR-51, LVK $\times$ LCR-038, TSKC $\times$ CTR-002, 'Flying Dragon' trifoliate and 'Swingle' citrumelo.

The results discussed in this paper were related to a young orchard, 18-month-old, and no differences were observed in the root system as a consequence of the practice of soil tillage, aimed at improving the quality of soil 
structure. Bordin et al. (2005) also found no type of compensation in the root growth of 'Pera' orange grafted on Rangpur lime due to soil scarification $(0.30 \mathrm{~m})$, after three years of this practice, in a 10-year-old orchard. In addition, neither soil bulk density nor total porosity was altered in the orchard interrows, regardless of depth and position relative to the plant. Minatel, Andrioli, Centurion, and Natale (2006) also found no improvements in soil physical properties (total porosity, macroporosity, microporosity, bulk density, mechanical resistance to vertical penetration, and hydraulic conductivity), after one year of subsoiling in a 16-year-old citrus orchard.

The higher vigor of plants grown from planting of nursery trees, in terms of root and shoot development, compared to plants directly sown at the definitive place in the field, may be associated with the quality of the nursery tree, due to either the care involved during the selection of the plants (without deformations in the root system and more vigorous) or the absence of limitations in terms of nutrition. The weather variability during the initial development of PS and the age of the orchard may also explain these differences. Long-term assessment throughout plant growth is necessary for better knowledge on citrus root system dynamics in the Coastal Tablelands, related to planting systems and their interactions with different rootstocks.

\section{Conclusions}

The practice of subsoiling did not affect the distribution of the root system, which was concentrated in the first $0.35 \mathrm{~m}$ of the soil, signaling that this effective depth is important for shoot and root development, due to the physical impediment caused by the cohesive horizons in soils of the Coastal Tablelands.

The planting of seedlings produced in protected environiment contributes to greater root development at shallow depths, allowing greater exploration of soil resources and, consequently, greater vegetative vigor in young plants of 'Pera' sweet orange, compared to the direct planting of seeds in the field.

\section{Acknowledgements}

To the National Council for Scientific and Technological Development (CNPq) for financially supporting M.A.C.F. (Process 311327/2015-0), to the Bahia Research Support Foundation (FAPESB) for granting the doctoral scholarship to T.N.M. and scientific initiation scholarship to L.L.A.S., and to the Coordination for the Improvement of Higher Education Personnel (CAPES) for supporting the Water and Soil Engineering Center (NEAS). M.A.C.F, A.S.G., O.S.P., H.P.S.F. and W.S.S.F. are funded by the Embrapa project (MP 03.16.05.023.00.00). To Mr. Roberto Toyohiro Shibata and his family for the support to the study conducted at Lagoa do Coco Farm, and to all the technical staff of Embrapa Cassava \& Fruits for the logistic support, especially to the agricultural technician Jorge Vieira.

\section{References}

Baldassari, R. B., Goes, A. D., \& Tannuri, F. (2003). Citrus blight: Is there something about the nursery trees production? Revista Brasileira de Fruticultura, 2(5), 357-360. https://doi.org/10.1590/S0100-29452003000 200047

Bordin, I., Neves, C. S. V. J., Ainda, F. T., Souza, W. R., Davoglio Junior, A. C., Furlaneto, T. L. R., \& Tavares Filho, J. (2005). Sistema radicular de plantas cítricas e atributos físicos do solo em um Latossolo argiloso submetido à escarificação. Ciência Rural, 35(4), 820-825. https://doi.org/10.1590/S0103-84782005000 400011

Calfa, C. H. (2010). Subsolagem em solo coeso de Tabuleiro Costeiro e desenvolvimento da lima da 'Pérsia'com porta-enxerto semeado no local definitivo do pomar (Unpublished doctoral thesis, Federal University of Bahia, Salvador, Brazil).

Carvalho, S. A. (2001). Propagação dos citros. Informe Agropecuário, 22(209), 21-25.

Cintra, F. L. D. (2006). Caracterização da região produtora: solo e clima. In M. B. Melo, \& L. M. S. Silva (Eds.), Aspectos técnicos dos citros em Sergipe (p. 82). Aracaju: Embrapa Tabuleiros Costeiros.

Cintra, F. L. D. (2011). Manejo de Solos Coesos dos Tabuleiros Costeiros. In M. B. D. Tofanelli \& T. O. Silva, (Eds.), Manejo Ecológico e Conservação dos Solos e da Água no Estado de Sergipe (1st ed., Cap. 5, pp. 205-226). São Cristóvão: UFS.

Coelho, E. F., Oliveira, F. C., Araújo, E. C. E., \& Vasconcelos, L. F. L. (2002). Distribuição de raízes de laranjeira 'Pera' sob sequeiro e irrigação por microaspersão em solo arenoso. Pesquisa Agropecuária Brasileira, 37(5), 603-611. https://doi.org/10.1590/S0100-204X2002000500005 
Davoglio Junior, A. C., Bordin, I., \& Neves, C. S. V. J. (2006). Sistema radicular e desenvolvimento de plantas cítricas provenientes de viveiro telado e aberto. Revista Brasileira de Fruticultura, 28(2), 172-175. https://doi.org/10.1590/S0100-29452006000 200004

Fidalski, J., Barbosa, G. M. C., Auler, P. A. M., Pavan, M. A., \& Beraldo, J. M. G. (2009). Qualidade física do solo sob sistemas de preparo e cobertura morta em pomar de laranja. Pesquisa Agropecuária Brasileira, 44(1), 76-83. https://doi.org/10.1590/S0100-204X2009000100011

González-Peñaloza, F. A., Cerdà, A., Zavala, L. M., Jordán, A., Giménez-Morera, A., \& Arcenegui, V. (2012). Do conservative agriculture practices increase soil water repellency? A case study in citrus-cropped soils. Soil and Tillage Research, 124, 233-239. https://doi.org/10.1016/j.still.2012.06.015

Gregory, P. J., Bengough, A. G., Grinev, D. V., Schmidt, S., Thomas, W. B. T. B., Wojciechowski, T., \& Young, I. M. (2009). Root phenomics of crops: Opportunities and challenges. Functional Plant Biology, 36(11), 922-929. https://doi.org/10.1071/FP09150

IBGE (Instituto Brasileiro de Geografia Estatística). (2017). Levantamento Sistemático da Produção Agrícola: Produção agrícola municipal. Retrieved from http://www.cnpmf.embrapa.br/Base_de_Dados/index_ pdf/dados/brasil/laranja/b1_laranja.pdf

Jin, K., White, P. J., Whalley, W. R., Shen, J., \& Shi, L. (2017). Shaping an Optimal Soil by Root-Soil Interaction. Trends in Plant Science, 22(10), 823-829. https://doi.org/10.1016/j.tplants.2017.07.008

Martins, C. R., Teodoro, A. V., \& Carvalho, H. W. L. (2014). Citricultura no Estado de Sergipe. Citricultura Atual, 17(103), 14-17.

Medeiros, J. C., Figueiredo, G. C., Mafra, Á. L., Rosa, J. D., \& Yoon, S. W. (2013). Deep subsoiling of a subsurface-compacted typical hapludult under citrus orchard. Revista Brasileira de Ciência do Solo, 37(4), 911-919. https://doi.org/10.1590/S0100-06832013000400008

Minatel, A. L. G., Andrioli, I., Centurion, J. F., \& Natale, W. (2006). Efeitos da subsolagem e da adubação verde nas propriedades físicas do solo em pomar de citros. Engenharia Agrícola, 26(1), 86-95. https://doi.org/ 10.1590/S0100-69162006000100010

Neves, M. F. (2010). O retrato da Citricultura brasileira (p. 138). Ribeirão Preto: Markestrat.

Oliveira, L. B., Coelho Filho, M. A., Arriero, S. S., Gomes Júnior, F. A., Cova, A. M. W., Soares Filho, W. S., \& Gesteira, A. S. (2018). Ability of citrus root system to overcome a strong wax layer. Journal of Agricultural Science, 10(10), 213-223. https://doi.org/10.5539/jas.v10n10p213

Passos, O. S, Cunha Sobrinho, A. P., \& Soares Filho, W. S. (2013). Cultivares copa. In C. Sobrinho, A. P. da Magalhães, A. F. de J. Souza, O. S. A. da S. Passos, \& W. dos S. Soares Filho (Eds.), Cultura dos citros (pp. 293-297). Brasília, DF: Embrapa.

Portella, C. R., Marinho, C. S., Amaral, B. D., Carvalho, W. S. G., Campos, G. S., Silva, M. P. S., \& Sousa, M. C. (2016). Desempenho de cultivares de citros enxertadas sobre o trifoliateiro 'Flying Dragon' e limoeiro 'Cravo' em fase de formação do pomar. Bragantia, 75(1), 70-75. https://doi.org/10.1590/1678-4499.267

Rezende, J. O. (2011). Um olhar sobre a citricultura do Estado da Bahia. Revista Bahia Agrícola, 9(1), $72-83$.

Rezende, J. O. (2013). O plantio direto dos citros: mito ou realidade? Revista Bahia Agrícola, 9(2), $72-85$.

Rezende, J. O., Shibata, R. T., \& Souza, L. S. (2015). "Plantio direto" dos citros. Justificativa e recomendações técnicas para o "plantio direto" dos citros nos tabuleiros costeiros: Enfase na citricultura dos Estados da Bahia e Sergipe (Vol. 1, pp. 88-101). Cruz das Almas, BA: Universidade Federal do Recôncavo da Bahia.

Rodrigues, M. J. D. S., Oliveira, E. R. M. D., Girardi, E. A., Ledo, C. A. D. S., \& Soares Filho, W. D. S. (2016). Produção de mudas de citros com diferentes combinações copa e porta-enxerto em viveiro protegido. Revista Brasileira de Fruticultura, 38(1), 187-201. https://doi.org/10.1590/0100-2945-284/14

Santana, M. B., Souza, L. S., Souza, L. D., \& Fontes, L. E. F. (2006). Atributos físicos do solo e distribuição do sistema radicular de citros como indicadores de horizontes coesos em dois solos de tabuleiros costeiros do estado da Bahia. Revista Brasileira de Ciência do Solo, 30(1), 1-12. https://doi.org/10.1590/S0100-0683 2006000100001

Santos, D. B., Coelho, E. F., \& Azevedo, C. A. V. (2005). Absorção de água pelas raízes do limoeiro sob distintas frequências de irrigação. Revista Brasileira de Engenharia Agrícola e Ambiental, 9, $327-333$. https://doi.org/10.1590/S1415-43662005000300006 
Souza, L. D., Cunha Sobrinho, A. P., Ribeiro, L. S., Souza, L. S., \& Ledo, C. A. S. (2004). Avaliação de plantas cítricas, em diferentes profundidades de plantio, em latossolo amarelo dos Tabuleiros Costeiros. Revista Brasileira de Fruticultura, 26(2), 241-244. https://doi.org/10.1590/S0100-29452004000200015

Souza, L. D., Ribeiro, L. S., Souza, L. S., Ledo, C. A. S., \& Cunha Sobrinho, A. P. (2006). Distribuição das raízes dos citros em função da profundidade da cova de plantio em Latossolo amarelo dos Tabuleiros Costeiros. Revista Brasileira de Fruticultura, 28(1), 87-91. https://doi.org/10.1590/S0100-2945200600 0100025

Souza, L. D., Souza, L. S., \& Ledo, C. A. S. (2007). Sistema radicular dos citros em Neossolo Quartzarênico dos Tabuleiros Costeiros sob irrigação e sequeiro. Pesquisa Agropecuária Brasileira, 42(10), 1373-1381. https://doi.org/10.1590/S0100-204X2007001000002

Souza, L. S., Souza, L. D., Paiva, A. Q., Rodrigues, A. C. V., \& Ribeiro, L. S. (2008). Distribuição do sistema radicular de citros em uma toposseqüência de solos de tabuleiro costeiro do estado da Bahia. Revista Brasileira de Ciência do Solo, 32(2), 503-513. https://doi.org/10.1590/S0100-06832008000200005

Zaccheo, P. V. C., Neves, C. S. V. J., Srenzel, N. M. C., \& Okumura, R. S. (2012). Distribuição do sistema radicular de porta-enxertos sob laranjeira 'Folha Murcha' em clima subtropical. Semina: Ciências Agrárias, 33(3), 921-930. https://doi.org/10.5433/1679-0359.2012v33n3p921

\section{Copyrights}

Copyright for this article is retained by the author(s), with first publication rights granted to the journal.

This is an open-access article distributed under the terms and conditions of the Creative Commons Attribution license (http://creativecommons.org/licenses/by/4.0/). 